\title{
ferfings Merke.
}

Eljter :Banto.

$s t \mathfrak{t} t \mathfrak{g} \mathfrak{a} \mathfrak{r}$.

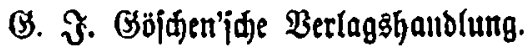

1869. 
8. Singlfubbruderti ३u Buttenberg (Eart Briininger) in Etuttgnt. 